\title{
Demam Berkepanjangan pada Anak di RSUP Fatmawati Tahun 2008-2010
}

\author{
Debbie Latupeirissa \\ SMF Kesehatan Anak, RSUP Fatmawati, Jakarta
}

\begin{abstract}
Latar belakang. Demam berkepanjangan merupakan penyebab penting morbiditas dan mortalitas pada anak, terutama di negara-negara tropis dan sedang berkembang. Diagnosis sering sulit ditentukan sehingga perlu diteliti etiologi dan karakteristik demam berkepanjangan pada anak, khususnya di RSUP Fatmawati, Jakarta.

Tujuan. Mengetahui karakterisrik penyebab demam berkepanjangan pada anak di RSUP Fatmawati.

Metode. Penelitian deskriptif retrospektif dilakukan untuk melihat karakteristik dan etiologi pasien demam berkepanjangan yang dirawat di SMF Kesehatan Anak RSUP Fatmawati. Populasi anak dengan diagnosis demam berkepanjangan diambil dari data rekam medis sejak Januari 2008 hingga Desember 2010.

Hasil. Angka kejadian pasien demam berkepanjangan di SMF Kesehatan Anak RSUP Fatmawati 0,68\% (60/8808 pasien), sebagian besar laki-laki. Rerata usia adalah 7,28 $\pm 3,91$ tahun. Penyebab terbanyak penyakit infeksi $97 \%$, yaitu demam tifoid, tuberkulosis paru dan infeksi saluran kemih. Sebagian besar pasien berusia $>6$ tahun, memiliki status gizi kurang. Kuman terbanyak ditemukan pada biakan darah dan urin yaitu Salmonella typhi dan E.coli.

Kesimpulan. Penyakit infeksi masih merupakan penyebab utama demam berkepanjangan pada anak.

Sari Pediatri 2012;14(4):241-5.
\end{abstract}

Kata kunci: demam berkepanjangan, anak

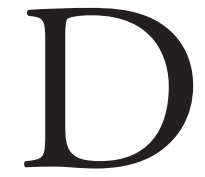

emam berkepanjangan masih menjadi masalah morbiditas dan mortalitas di negara-negara tropis dan sedang berkembang, ${ }^{1}$ dan etiologi berbedabeda tergantung letak geografis dan status sosioekonomi suatu negara. ${ }^{2}$ Demam persisten

\section{Alamat korespondensi:}

Dr. Debbie Latupeirissa, Sp.A. SMF Kesehatan Anak RSUP Fatmawati, Jakarta. Telp. (021) 7501524, Fax: (021) 75911454 E-mail: debbie_ latupeirissa@yahoo.com berkepanjangan adalah demam berlangsung lebih dari delapan hari dan evaluasi di rumah sakit kadang-kadang gagal mendeteksi penyebab demam. ${ }^{3}$ Pada tahun 1961 demam persisten berkepanjangan didefinisikan sebagai demam dengan suhu $>38,4^{\circ} \mathrm{C}\left(101.2^{\circ} \mathrm{F}\right)$ yang berlangsung tiga minggu atau lebih dan pencarian diagnosis yang tidak jelas setelah satu minggu di rumah sakit. ${ }^{3,4}$ Karena progresifitas penyakit pada anak lebih cepat dibandingkan dewasa dan menimbulkan efek yang jelas terhadap kesehatan anak, maka penggunaan 
waktu tiga minggu pada anak dianggap tidak praktis.

Tiga penyebab terbanyak demam persisten berkepanjangan yaitu penyakit infeksi (60\%-70\%), penyakit kolagen-vaskular, dan keganasan. ${ }^{1-8}$ Walaupun infeksi virus sangat jarang menjadi penyebab demam berkepanjangan, tetapi $20 \%$ penyebab adalah infeksi virus. ${ }^{9}$ Suatu pengamatan terhadap 221 kasus demam persisten berkepanjangan pada anak di Kuwait mendapatkan $78 \%$ disebabkan oleh infeksi, 5\% penyakit kolagen dan 2\% keganasan. Sekitar 15\% tidak terdeteksi penyebabnya. Brucella adalah penyebab infeksi terbanyak (38\%), diikuti dengan demam tifoid $9 \% .^{10}$

Kesulitan mencari penyebab demam berkepanjangan disebabkan oleh banyak faktor. Terdapat lebih kurang 200 penyebab demam berkepanjangan yang menimbulkan kesulitan mendiagnosis etiologi demam berkepanjangan dalam waktu singkat. ${ }^{11}$ Pencarian penyebab terkadang dihubungkan dengan keadaan geografis tempat pasien tinggal, anamnesis yang kurang lengkap, dan pemeriksaan fisik yang kurang teliti sehingga hal penting yang seharusnya dapat mendukung diagnosis tidak ditemukan.

\section{Metode}

Penelitian observasional deskriptif untuk mengetahui angka kejadian dan karakteristik demam berkepanjangan pada anak di RSUP Fatmawati. Data diambil dari rekam medik semua anak berusia 3 bulan $-<14$ tahun saat masuk perawatan di ruang rawat IRNA A SMF Kesehatan Anak RSUP Fatmawati sejak Januari 2008 - Desember 2010 dengan diagnosis demam berkepanjangan yaitu demam yang berlangsung lebih dari 2 minggu dan diagnosis pasti belum diketahui. Diagnosis akhir dibuat berdasarkan pemeriksaan laboratorium darah tepi, urin lengkap, feses lengkap, analisis cairan serebrospinal, serologi, kultur spesimen darah dan urin, ASTO, dan C reactive protein. Juga berdasarkan pemeriksaan foto toraks dan ultrasonografi abdomen, serta uji tuberkulin. Tidak terdiagnosis apabila sampai pasien pulang rawat hanya tercatat diagnosis demam berkepanjangan dengan kecurigaaan infeksi virus atau bakteri. Kriteria dieksklusi apabila data tidak lengkap.

\section{Hasil}

Selama kurun waktu pengamatan didapatkan 60 kasus dengan diagnosis demam berkepanjangan yang memenuhi kriteria inklusi dan eksklusi terdiri atas 33 (55\%) laki-laki dan 27 (45\%) perempuan. Berdasarkan pembagian menurut kelompok usia, terbanyak $>6$ tahun (50\%), diikuti 3-36 bulan $(28,3 \%)$ dan $>36$ bulan-6 tahun (21,7\%). Rerata usia 7,28 $\pm 3,91$ tahun. Status gizi terdiri atas gizi kurang $(55,8 \%)$, diikuti gizi baik (39,5\%), 2 pasien dengan gizi lebih, dan tidak didapatkan pasien dengan gizi buruk.

Infeksi merupakan penyebab terbanyak 58 (97\%) demam berkepanjangan, dan penyakit lain 2 anak (3\%), demam tifoid 21 pasien sedangkan infeksi virus didapatkan pada 10 pasien (15\%).

Infeksi bakteri terbanyak pada usia 3-36 bulan dan di atas 6 tahun, sedangkan infeksi virus pada anak usia 3-36 bulan. Pada kelompok usia 3-36 bulan penyakit infeksi tersering adalah tuberkulosis paru dan infeksi saluran kemih, sedangkan usia $>6$ tahun adalah demam tifoid. Infeksi tuberkulosis paru sering disertai gizi kurang dibandingkan penyebab infeksi lain, sedangkan demam tifoid lebih banyak pada anak dengan status gizi baik. Terdapat 15 kasus yang tidak terdiagnosis dan hanya diduga infeksi bakteri atau virus.

Jumlah leukosit normal didapatkan pada infeksi oleh bakteri ataupun virus. Leukosit $\geq 15.000 / \mathrm{mm} 3$ terdapat pada demam berkepanjangan karena infeksi bakteri.

Tabel 1. Sebaran usia menurut jenis kelamin dan status gizi

\begin{tabular}{lccccc}
\hline & \multicolumn{2}{c}{ Jenis kelamin } & \multicolumn{2}{c}{ Status gizi } \\
\cline { 2 - 6 } Usia & $\begin{array}{c}\text { Laki-laki } \\
(\mathrm{n}=33)\end{array}$ & $\begin{array}{c}\text { Perempuan } \\
(\mathrm{n}=27)\end{array}$ & Baik & Kurang & Lebih \\
\hline 3-36 bulan & 11 & 6 & 4 & 9 & 0 \\
$>$ 36 bulan -6 tahun & 8 & 5 & 5 & 1 & 2 \\
$>$ 6 tahun & 14 & 16 & 8 & 14 & 0 \\
\hline
\end{tabular}


Tabel 2. Distribusi penyebab, sebaran usia, dan status gizi

\begin{tabular}{|c|c|c|c|c|c|c|c|}
\hline \multirow{2}{*}{ Diagnosis } & \multicolumn{4}{|c|}{ Usia (bulan-tahun) } & \multicolumn{3}{|c|}{ Status gizi } \\
\hline & $\mathrm{n}$ & $3-36$ & $>36-6$ & $>6$ & Baik & Kurang & Lebih \\
\hline \multicolumn{8}{|l|}{ Infeksi bakteri } \\
\hline Demam tifoid & 21 & 1 & 5 & 15 & 9 & 5 & 1 \\
\hline Infeksi saluran kemih & 7 & 3 & 2 & 2 & 1 & 5 & 0 \\
\hline TB paru & 10 & 5 & 0 & 5 & 2 & 7 & 0 \\
\hline Leptospirosis & 1 & 1 & 0 & 0 & 1 & 0 & 0 \\
\hline Pneumonia atipik & 1 & 0 & 0 & 1 & 0 & 0 & 0 \\
\hline Meningitis TB & 1 & 1 & 0 & 0 & 0 & 1 & 0 \\
\hline Meningoensefalitis & 1 & 0 & 1 & 0 & 1 & 0 & 0 \\
\hline Apendisitis akut & 1 & 0 & 0 & 1 & 0 & 1 & 0 \\
\hline Tidak terdiagnosis & 8 & 2 & 2 & 4 & 0 & 2 & 1 \\
\hline \multicolumn{8}{|l|}{ Infeksi virus } \\
\hline Demam berdarah dengue & 1 & 0 & 0 & 1 & 0 & 1 & 0 \\
\hline Hepatitis B & 1 & 1 & 0 & 0 & 0 & 0 & 0 \\
\hline HIV & 1 & 1 & 0 & 0 & 0 & 1 & 0 \\
\hline Tidak terdiagnosis & 7 & 3 & 2 & 2 & 1 & 3 & 0 \\
\hline \multicolumn{8}{|l|}{ Lainnya } \\
\hline Demam rematik & 2 & 0 & 2 & 0 & 1 & 0 & 0 \\
\hline
\end{tabular}

Tabel 3. Hasil pemeriksaan jumlah leukosit

\begin{tabular}{lccc}
\hline \multirow{2}{*}{ Jumlah leukosit $\left(\mathrm{mm}^{3}\right)$} & \multicolumn{2}{c}{ Etiologi FUO : Infeksi } & Total \\
\cline { 2 - 3 } & Bakteri & Virus & \\
\hline$<5000$ & 11 & 4 & 15 \\
$5000-15000$ & 26 & 7 & 33 \\
$\geq 15000$ & 10 & 0 & 10 \\
\hline Total & 45 & 11 & 58 \\
\hline
\end{tabular}

\section{Pembahasan}

Angka kejadian demam berkepanjangan di RSUP Fatmawati periode tahun 2008-2010 adalah 0,68\% dari seluruh pasien dirawat (8808 pasien). Angka kejadian tersebut sesuai dengan estimasi Long $\mathrm{dkk}^{6}$ sekitar $0,5-3 \%$. Penelitian sebelumnya mendapatkan infeksi tersering sekitar 40\%-60\%, diikuti penyakit autoimun 7\%-20\%. ${ }^{6,9,12}$ Penelitian oleh Bakry dkk ${ }^{13}$ terhadap anak dengan demam berkepanjangan yang dirawat di Departemen Ilmu Kesehatan Anak FKUI/ RSCM mendapatkan $80 \%$ disebabkan oleh infeksi. Pada penelitian kami, 97\% penyebab adalah infeksi dan 3\% oleh sebab lainnya. Hal tersebut terjadi akibat faktor wilayah, Indonesia adalah negara berkembang sehingga penyakit infeksi masih cukup tinggi. ${ }^{2}$

Demam tifoid merupakan penyebab tersering dibandingkan infeksi lain, terutama pada anak berusia $>6$ tahun. Sesuai dengan kepustakaan bahwa diperkirakan lebih dari 21,7 juta kasus demam tifoid terjadi pertahun, dan mayoritas kejadian terdapat di Asia. Di banyak negara berkembang, kejadian demam tifoid $<15$ kasus per 100.000 populasi, sebaliknya di negara sedang berkembang, angka kejadian 100-1000 kasus per 100.000 populasi. Terdapat perbedaan distribusi usia dan populasi yang mengalami risiko. Suatu studi pada populasi dari Asia Selatan mengindikasikan bahwa insidens terbanyak pada usia $<5$ tahun. Sedangkan di Indonesia (daerah endemis) dilaporkan antara 3-19 tahun mencapai 91\% kasus. Angka yang kurang lebih sama juga dilaporkan dari Amerika Selatan. ${ }^{14}$

Sebagian besar pasien adalah laki-laki, sesuai dengan penelitian yang dilakukan dalam penelitian sebelumnya. ${ }^{1,2,9,12,13}$ Status nutrisi juga merupakan aspek yang penting karena dapat mempengaruhi perjalanan 
dan prognosis penyakit. Sebagian besar pasien yang diteliti adalah status gizi kurang. Hal tersebut sejalan dengan penelitian Cogulu dkk ${ }^{12}$ dan Bakry $\mathrm{dkk}^{13}$ yang menemukan 35\% kasus memiliki berat badan di bawah persentil 3 NCHS.

Untuk menegakkan diagnosis dan menyingkirkan diagnosis banding demam berkepanjangan, diperlukan pemeriksaan penunjang dengan mempertimbangkan dugaan etiologi berdasarkan usia, iklim, epidemiologi, dan faktor pejamu. ${ }^{15}$ Pada penelitian kami, pada semua pasien dilakukan pemeriksaan darah rutin dan urin rutin. Pemeriksaan lanjutan seperti biakan darah dan urin, serta uji tuberkulin juga sering dilakukan pada pasien yang diteliti. Pada beberapa pasien sulit dilakukan pemeriksaan penunjang lanjutan karena masalah biaya sehingga diagnosis beberapa kasus hanya berdasarkan penemuan klinis saja. Hitung leukosit dilakukan terhadap semua pasien. Dari 58 pasien yang disebabkan oleh infeksi terdiri atas 45 pasien disebabkan bakteri, dan 11 disebabkan virus. Jumlah leukosit sebagian besar normal dan leukopenia, dan jarang leukositosis pada infeksi bakteri. Laporan dari Inggris juga mendapatkan hasil yang sama yaitu sebagian besar pasien dengan infeksi yang serius jarang menunjukkan leukositosis dengan sensifisitas hanya $10 \%$, spesifisitas $95 \%$, dan nilai prediktif positif 44\%. ${ }^{16}$ Di Iran pada 61 pasien infeksi saluran kemih, sebagian besar tidak terdapat leukositosis. ${ }^{18}$ Pemeriksaan serologis IgM anti Salmonella typhi merupakan pemeriksaan serologis yang sering dilakukan. Pada 4/8 pasien demam tifoid dengan biakan darah, menunjukkan hasil positif yaitu serologis IgM anti Salmonella typhi. ${ }^{5}$

Kuman terbanyak yang ditemukan pada biakan darah adalah Salmonella typhi.sedangkan pada biakan urin adalah Escherichia coli. Hal tersebut sesuai dengan laporan dari Thailand yang menemukan kuman E.coli dan Salmonella merupakan penyebab terbanyak. ${ }^{17}$ Demikian pula di Kuwait yang mendapatkan pasien demam tifoid dengan hasil kultur Salmonella typhi. ${ }^{10}$

Disimpulkan bahwa angka kejadian demam berkepanjangan di SMF Kesehatan Anak periode Januari 2008 sampai Desember 2010 sebesar 0,68\%. Sebagian besar pasien adalah laki-laki dengan status gizi terbanyak adalah gizi kurang. Infeksi merupakan penyebab tersering demam berkepanjangan dan sebagian besar disebabkan oleh demam tifoid, tuberculosis, dan infeksi saluran kemih. Infeksi virus didapatkan pada $15 \%$ kasus. Jumlah leukosit $\geq 15000$ / $\mathrm{mm}^{3}$ ditemukan pada semua kasus yang disebabkan oleh infeksi bakteri. Hasil biakan terbanyak yaitu Salmonella typhi dan E.coli.

\section{Daftar pustaka}

1. Miller LC, Sisson BA, Tucker LB, Schaller JG. Prolonged fevers of unknown origin in children : patterns of presentation and outcome. J Pediatr 1996:129:419-23.

2. Bakashvili LZ, Makhviladze MA, Pagava EK, Pagava KI. Fever of unknown origin in children and adolescents in Georgia : a review of 52 patients. Georgian Med News 2006;135:66-9.

3. Palazzi DL, Feigin RD. Fever without source and fever of unknown origin. Dalam: Feigin RD, Cherry JD, Demmler GJ, Kaplan SL,penyunting. Textbook of Pediatric, infectious diseases. Edisi ke-6. Philadelphia:Elsevier; 2009.h.851-62.

4. Petersdorf RG, Beeson PB. Fever of unexplained origin: report on 100 cases. Medicine 1961;40:1.

5. Chantada G, Casak S, Plata JD, Pociecha J, Bologna R. Children with fever of unknown origin in Argentina: an analysis of 113 cases. Pediatrr Infect Dis J.1994; 13:260-3.

6. Chouchane S, Chouchane $\mathrm{CH}$, Ben Meriem $\mathrm{CH}$. Prolonged fever in children. Retrospective study of 67 cases. Arch Pediatr 2004;11:1319-25.

7. Colpan A, Onguru P, Erbay A, Akinci E. Fever of unknown origin : analysis of 71 consecutive cases. Am J Med Sci2007:334:92-6.

8. Joshi N, Rajeshwari K, Dubey AP. Clinical spectrum of fever of unknown origin among Indian children. Ann Trop Paediatr 2008:28:261-6.

9. Chien CH, Lee CY, Huang LM. Prolonged fever in children. Zhonghua Min Gio Xiao Er Ke Yi Xue Hui Za Zhi 1996;37:31-8.

10. Mouaket AE, el-Ghanim MM, Abd-el-Al YK, al-Quod N. Prolonged unexplained pyrexia: A review of 221 paediatric cases from Kuwait. Infection 1990; 18:2269.

11. Teach SJ. Approach to the child with prolonged fever in the pediatric emergency department. Clin Pediatr Emerg Med J 2000;1:157-63.

12. Cogulu O, Koturoglu G, Kurugol Z. Evaluation of 80 children with prolonged fever. Paediatr Drugs 2003;45: 564-9.

13. Bakry BA, Tumbelaka AR, Chair I. Etiologi dan karakteristik demam berkepanjangan pada anak di RS. Dr.Cipto Mangunkusimo, Jakarta. Sari Pediatri 
2008;10:83-8.

14. Soedarmo SSP, Garna H, Hadinegoro SRS, Satari HI, penyunting. Demam Tifoid. Buku Ajar Infeksi Tropis. Jakarta: Edisi kedua. IDAI; 2008.

15. Akpede GO, Akenzua GI. Aetiology and management of children with acute fever of unknown origin.Paediatr Drugs 2001;3:169-93.

16. Nademi Z, Clark J, Richards CG. The causes of fever in children attending hospital in the north of England.
J Infect 2001:43:221-5.

17. Leelarasamee A, Chupaprawan C, Chenchittikul M, Udompanthurat. Etiologies of acute undifferentiated febrile illnessin Thailand. J Med Assoc Thai 2004; 87:464-72.

18. Naseri M. Alterations of peripheral leukocyte count, erythrocyte sedimentation rate, and C-reactive protein in febrile urinary tract infection. Iran J Kidney Dis 2008;2:137-42. 